\title{
ReSEARChArticle \\ Knowledge of improved aonla cultivation by the tribal women of Udaipur district, Rajasthan
}

\author{
Vandana Vishwakarma, Snehlata Maheshwari and Dhriti Solanki
}

\begin{abstract}
SUMMARY
Aonla or Indian gooseberry (Emblica officinalis Gaertn) is a wonderful fruit and one of the precious gifts of nature to man. The popular use of this fruit is in indigenous medicines (Ayurvedic system) viz., trifla and chayavanprash. In addition, the aonla fruits are preserved and sold in the form of murabba, pickles, candy, jelly and jam. Aonla is an important and highly valued fruit grown in India. There is a wide scope to improve and increase the aonla production by enhancing the knowledge regarding improved aonla cultivation. Knowledge plays an important role in adoption of improved cultivation and post harvest practices of aonla. The present study was conducted in Jhadol panchayt samiti of Udaipur district, Rajasthan to assess knowledge of tribal women regarding improved aonla cultivation and post harvest practices. Total ten villages were selected from three clusters viz., Ogna, Jhadol and Baghpura. A sample of 200 tribal women was selected through random sampling technique from selected villages with proportion to the size of sample in the selected villages. Selected respondents were interviewed personally using well structured pre tested interview schedule. The collected data were analyzed by using appropriate statistical tool to infer results. The study revealed that the respondents possessed average knowledge with overall MPS 64.87 regarding improved cultivation practices of aonla. Knowledge assessment of the respondents regarding post harvest practices showed that they possessed average knowledge about post harvest practices with overall MPS 55.46.
\end{abstract}

Key Words : Knowledge, Cultivation, Post harvest practices, Aonla, Tribal women

How to cite this article : Vishwakarma, Vandana, Maheshwari, Snehlata and Solanki, Dhriti (2021). Knowledge of improved aonla cultivation by the tribal women of Udaipur district, Rajasthan. Internat. J. Plant Sci., 16 (2): 118-125, DOI: 10.15740/HAS/IJPS/16.2/ 118-125, Copyright@ 2021: Hind Agri-Horticultural Society.

Article chronicle : Received : 28.02.2021; Revised : 19.03.2021; Accepted : 24.04.2021

MEMBERS OF THE RESEARCH FORUM

Author to be contacted :

Vandana Vishwakarma, Faculty of Home Science, Kamla Nehru

Institute of Physical and Social Sciences, Sultanpur (U.P.) India

Email : vandana27.sln@gmail.com 